APPROPRIATELY INDIAN 



\section{APPROPRIATELY INDIAN}

GENDER AND CULTURE IN A NEW TRANSNATIONAL CLASS

Smitha Radhakrishnan

Duke University Press

Durham and London 2011 
(C) 2011 Duke University Press

All rights reserved

Printed in the United States of America on acid-free paper $\infty$

Designed by Heather Hensley

Typeset in Chapparel Pro by Keystone

Typesetting, Inc.

Library of Congress Cataloging-in-

Publication Data appear on the last printed page of this book. 
For Avva, who first inspired me to write

about the everyday life that surrounds me. 
